\title{
GOAL SETTING, VALUES OF BINUS, DAN PEMBELAJARAN CHARACTER BUILDING DI BINUS UNIVERSITY
}

\author{
Yustinus Suhardi Ruman \\ Character Building Development Center, BINUS University \\ Jln. Kemanggisan Ilir III No. 45, Kemanggisan-Palmerah, Jakarta Barat 11480 \\ y_suhardi@yahoo.com
}

\begin{abstract}
Character Building Education in this era has become concerning by so many institutions of education. Institution of education is not only preparing the student to have knowledge or become smart, cleaver, but also preparing them to become good person. Of course, there are so many definitions about good person. But in this paper, author means that the good person is they who are not only having soft skill like communication skills, leadership skills, team work skills, initiative \& enterprise skills, organization skills, problem solving and ethical decisions making skills. All these skills are very important for every people on this era. It is difficult to think about people will gain a success without mastering these skill. According to author, all the skills above, although important, they are not enough. All the skills must be built on certain values. In this context both hard skills and soft skills should be based on certain values. As an institution of education, Binus University has certain values. They consist of trust in God, farsighted, freedom to innovate, embrace diversity and tenacious focus. The attitude and behavior of all binusian has to reveal these values. Character Building learning on this point is not only coaching the student in mastering the soft skill above, but also to internalize the values of Binus. So, Values of Binus will inspire all binusian. This paper explains the position of character building learning as a goal setting to internalize the values of binus. To describe the position of character building learning, author uses the concept social action of Talcott Parson.
\end{abstract}

Keywords: character building, values of Binus, goal setting

\begin{abstract}
ABSTRAK
Pendidikan Character Building di era ini telah menjadi perhatian bagi begitu banyak lembaga pendidikan. Lembaga pendidikan tidak hanya mempersiapkan siswa untuk memiliki pengetahuan atau menjadi cerdas dan pintar, tetapi juga mempersiapkan mereka untuk menjadi orang baik. Tentu saja, ada begitu banyak definisi tentang orang baik. Namun dalam tulisan ini, yang dimaksudkan penulis tentang orang baik adalah mereka yang tidak hanya memiliki soft skill seperti keterampilan komunikasi, keterampilan kepemimpinan, keterampilan tim kerja, keterampilan inisiatif dan perusahaan, keterampilan organisasi, pemecahan masalah, dan keterampilan dalam mengambil keputusan etis. Semua keterampilan ini sangat penting bagi setiap orang di era ini. Sulit untuk berpikir tentang orang-orang akan meraih sukses tanpa menguasai keterampilan ini. Menurut penulis, semua keterampilan di atas, meskipun penting, tidaklah cukup. Semua keterampilan harus dibangun di atas nilai-nilai tertentu. Dalam konteks ini baik hard skill dan soft skill harus didasarkan pada nilai-nilai tertentu. Sebagai lembaga pendidikan, Binus University memiliki nilai-nilai tertentu. Nilai-nilai itu terdiri dari kepercayaan pada Tuhan, berpandangan jauh, kebebasan untuk berinovasi, menghargai keragaman dan ulet teguh. Sikap dan perilaku semua binusian harus menunjukkan nilai-nilai ini. Pendidikan Character Building pada titik ini bukan hanya pembinaan siswa dalam menguasai soft skill di atas, tetapi juga untuk menginternalisasi nilai-nilai Binus. Jadi, Nilai dari Binus akan menginspirasi semua binusian. Tulisan ini akan menjelaskan posisi pembelajaran character building sebagai goal setting untuk menginternalisasi nilai-nilai Binus. Untuk menggambarkan posisi pembelajaran character building, penulis menggunakan konsep aksi sosial Talcott Parson.
\end{abstract}

Kata kunci: character building, values of Binus, goal setting 


\section{PENDAHULUAN}

Salah satu fungsi pembelajaran pada umumnya adalah menyiapkan peserta didik menghadapi masa depan. Masa depan pada prinsipnya merupakan sebuah proyeksi atau dapat juga disebut sebagai sebuah cita-cita. Meskipun sebuah proyeksi atau cita-cita, masa depan merupakan bagian dari masa sekarang, sama persis ketika masa sekarang yang pernah menjadi bagian dari proyeksi masa lalu. Oleh karena itu, masa sekarang selalu memuat jejak masa lalu dan masa depan selalu berawal pada saat ini. Hidup manusia atau seorang individu atau aktor dalam konteks ini merupakan sebuah continuum dan bersifat linear. Sikap dan perilaku yang ditampilkan pada saat ini selalu merupakan refleksi dari suatu sejarah yang panjang dari masa lalu. Bila ditempatkan pada konteks sosiologi Bourdieu (Wallace \& Wolf, 2005: 114-116), kualitas refleksi tersebut disebut sebagai habitus.

Bourdieu (Ritzer \& Goodman, 2004: 581) menjelaskan bahwa habitus adalah struktur mental atau kognitif yang digunakan untuk memersepsi, memahami, mengapresiasi dan mengevaluasi dunia sosial. Secara dialektis, habitus merupakan produk dari internalisasi struktur dunia sosial. Dalam dunia sosial tidak setiap orang berada pada stuktur sosial yang sama. Ini berarti bahwa tidak setiap orang memiliki persepsi dan pemahaman yang sama mengenai dunia obyektif yang mereka hadapi. Oleh karena itu, menurut Bourdieu, orang yang berasal dari posisi, kelopok status sosial yang sama dalam masyarakat cenderung memiliki habitus yang sama, dan terhadap orang yang berasal dari status dan posisi yang berbeda habitusnya juga cenderung berbeda.

Bertolak dari penjelasan Bourdieu di atas, maka dapat diasumsikan bahwa setiap peserta didik yang berasal dari berbagai latar belakang yang berbeda memiliki habitus yang berbeda pula. Mereka memiliki pandangan tentang dunia yang berbeda. Dan oleh karena itu, refleksi mereka mengenai hal yang perlu mereka lakukan juga pasti berbeda. Dalam konteks ini, pertanyaan yang perlu dianalisis terus menerus adalah mengenai fungsi sebuah lembaga pendidikan.

Sebuah lembaga pendidikan mengikuti logika Bourdieu juga memiliki habitus sendiri. Habitus itu, bisa berupa refleksi para pendiri mengenai cita-cita mereka pada masa lalu tentang sebuah masa yang sedang dihayati sekarang. Secara historis, mereka adalah produk atau konstruksi dari sejarah panjang yang mereka alami sepanjang hidup mereka. Oleh karena itu, sebuah lembaga pendidikan dapat disebut sebagai suatu institusionalisasi dari sebuah cita-cita yang diproduksi dan konstruksi oleh sejarah hidup mereka yang panjang sebelumnya.

Ketika para peserta didik memasuki sebuah lembaga pendidikan yang dalam konteks Bourdieu dapat disebut sebagai institusionalisasi habitus para pendiri, maka para peserta didik dengan habitus yang berbeda akan belajar mereproduksi dan merekonstruksi sebuah habitus baru. Dalam mereproduksi dan merekonstruksi tersebut, para peserta didik diharapkan memiliki habitus yang relatif sama terutama tentang pandangan tentang dunia di masa depan. Habitus yang sama tersebut akan membedakan peserta didik lain yang berasal dari habitus yang berbeda. Secara lebih konkret dapat dirumuskan habituslah yang membedakan binusian dari nonbinusian.

Fokus utama dari tulisan ini adalah pembelajaran Character Building sebagai goal setting. Diasumsikan bahwa pembelajaran Character Building pada Binus University merupakan bagian dari usaha mereproduksi dan merekonstruksi kembali nilai-nilai, pandangan hidup, kebiasaan para pendiri dari masa lalu sesuai dengan tantangan yang ada dalam dunia sosial sekarang ini dan persespsi mengenai dunia sosial yang akan terjadi masa depan. 


\section{METODE PENELITIAN}

Penulisan artikel ini tidak didasari pada penelitian lapangan. Semua analisis yang dilakukan oleh penulis dalam artikel ini berdasarkan pada studi kepustakaan. Meskipun demikian, pendekatan metodologik yang digunakan oleh penulis adalah pendekatan struktur. Oleh karena itu, semua kerangka teori yang digunakan untuk membahas fokus analisis berasal dari teori-teori yang digunakan dalam pendekatan struktur. Ada pun teori yang digunakan sebagai kerangka acuan analisis adalah teori tindakan sosial yang diperkenalkan oleh Talcott Parson.

Berdasarkan kerangka metodologik tersebut, penulis akan menganalisis bagaimana goal dan goal setting tidak semata-mata lahir dari kemampuan dan keterampilan individu dalam menghadapi dunianya, melainkan juga ditentukan oleh faktor-faktor eskternal seperti budaya dan faktor-faktor situasional dan kondisonal. Budaya selalu mengandung dimensi-dimensi seperti: pandangan hidup, nilai-nilai, norma, kebiasaan. Budaya juga mencakup sikap dan berilaku serta teknologi yang dihasilkan. Dimensi-dimensi ini berkaitan satu dengan yang lainnya. Rekayasa kurikulum dalam konteks ini memuat pandangan-pandangan, nilai-nilai dan kepercayaan-kepercayaan Binus tentang dunia sosial yang akan dihadapi oleh para lulusannya. Sedangkan proses induksi dosen, kegiatan kurikuler dan ekstrakurikuler yang wajib diikuti oleh setiap mahasiswa tidak lain dari proses institusionalisasi budaya ke dalam stuktur kepribadian para binusian. Sehingga dengan demikian, baik sikap maupun teknologi yang dihasilkan mencerminkan nilai-nilai Binusian.

Pembelajaran Character Building dalam konteks ini, dianggap sebagai salah satu goal setting yang dapat merekonstruksi dan mereproduksi habitus mahasiswa sehingga dengan demikian akan lahir para binusian. Para binusian tidak saja memiliki hard skill dan soft skill sebagaimana yang dibutuhkan dalam dunia sosial baik saat ini maupun masa yang akan datang, tetapi juga mecerminkan habitus binus. Para binusian bukan hanya karena mereka lulusan Binus, tetapi terutama karena mereka mencerminkan nilai-nilai, pandangan-pandangan dan kepercayaan-kepercayaan Binus tentang sebuah dunia sosial baik yang sekarang sedang berkembang maupun masa depan yang akan terus berproses.

\section{HASIL DAN PEMBAHASAN}

\section{Goal Setting}

Ulasan-ulasan yang berkaitan dengan goal setting banyak kita jumpai dalam buku-buku yang berhubungan dengan keterampilan interpersonal dalam organisasi. Janasz, Down \& Schneider (2006: 48) mendefinisikan goal setting sebagai alat untuk mengidentifikasi prioritas kerja dan hidup dan mengembangan strategi-strategi untuk mencapai tujuan-tujuan personal dan profesional.

Berdasarkan penjelasan ini, Janasz, Down \& Schneider tentu saja tidak memberi definisi mengeni goal setting, mereka hanya mengemukakan aspek fungsional dari goal setting yakni sebagai instrumen untuk mengidentifikasi dan mengembangkan prioritas dan strategi untuk mencapai tujuan personal dan profesional. Dengan penjelasan seperti itu, maka goal setting dapat dimaknai sebagai sebuah kerangka kerja untuk mencapai suatu visi yang masih jauh ke depan. Dalam hal ini kita perlu membedakan antara goal setting dan goal.

Goal di satu sisi pada dasarnya menyangkut aspek futuristik, sesuatu yang akan terjadi pada masa depan. Goal dalam hal ini tidak berkaitan dengan apa yang terjadi dan harus terjadi masa sekarang, kini dan di sini (hic et nunc). Sedangkan goal setting pada sisi yang lain berhubungan dengan bagaimana aspek futuristik itu disadari, ditetapkan, dirumuskan dan juga dicapai. Oleh karena 
itu, goal setting berbicara tentang saat ini, tentang hal yang harus dimiliki dan dilakukan oleh orang saat ini untuk menuju dan mencapai masa depan.

Janasz, Down \& Schneide mengemukakan bahwa setiap orang yang memiliki goal setting akan memperoleh beberapa manfaat seperti: 1) manfaat moral/esteem yakni pencapaian sebuah tujuan memberikan seseorang suatu penguatan internal mengenai kemampuan pribadi; 2) goal setting juga memberi tujuan dan arah mengenai hal yang hendak dicapai; 3) selain itu, goal setting dapat membangun sebuah motivasi untuk mengarahkan tindakan pada pemenuhan mimpi dan ambisi; dan terakhir, 4) goal setting memberikan kita suatu cara untuk mengukur pencapaian kita. Sehingga dengan demikian, secara sistematik, goal setting menyediakan suatu keseimbangan dan perspektif bagi keputusan kita mengenai bagaimana mengalokasikan waktu dan sumber daya.

Selain menjelaskan manfaat dari adanya goal setting untuk mencapai tujuan yang ingin diperoleh, Janasz, Down \& Schneide menganjurkan beberapa perilaku penting dalam membuat sebuah goal setting. Beberapa perilaku tersebut adalah being realistic, yakni jujur dengan diri sendiri mengenai kemampuan dan keterampilan dalam mengevaluasi semua kondisi yang dibutuhkan untuk mencapai tujuan tersebut. Seseorang hanya dapat memengaruhi dan mengubah sesuatu yang ia dapat kontrol. Perilaku yang kedua adalah sikap positif. Manusia menghadapi hambatan dan tantangan dalam segala sesuatu yang dilakukan. Kemampuan untuk bertahan dalam menghadapi berbagai tawaran merupakan faktor kunci sukses dalam goal setting. Dalam kondisi seperti ini sikap positif untuk tetap pada fokus menjadi sangat penting. Sikap yang ketiga adalah mulai dari yang kecil.

Kesempurnaan dalam menyelesaikan tujuan-tujuan kecil akan membantu rasa percaya diri dan menciptakan momentum terhadap perilaku goal setting pada masa yang akan datang. Perilaku yang keempat adalah mengambil tanggung jawab penuh. Meskipun membutuhkan bantuan orang lain dan dukungan dari sahabat, kontrol tindakan tetap pada diri sendiri. Tentukan tujuan dengan pemahaman bahwa kekuasaan untuk mengarahkan tenaga pada produktivitas pribadi dimiliki. Perilaku yang terakhir adalah pemeliharaan dan ketekunan. Setiap orang diharapkan tetap memelihara cita-cita dan dengan tekun berusaha untuk mencapainya.

Untuk menentukan tujuan (goal) yang ingin dicapai, mulailah dengan mengklarifikasi nilainilai diri sendiri, segala sesuatu dalam hidup yang sungguh bermakna bagi diri pribadi. Nilai adalah pandangan pribadi atau pendapat yang dipegang teguh. Nilai dalam konteks ini dapat dijadikan sebagai panduan untuk memilih instrumen atau cara yang digunakan untuk mencapai sebuah goal. Nilai juga dapat menjadi pegangan dalam menentukan cita-cita atau tujuan (goal). Nilai sangat dipengaruhi oleh keluarga, teman-teman, kelompok sebaya, kepercayaan agama, komunitas dan bahkan organisasi-organisasi yang diasosiasikan dengan diri sendiri.

Milton Rokeach mengidentifikasi dua nilai umum yakni instrumental values dan terminal values. Instrumental values merupakan standar-standar perilaku yang dengan melaluinya tujuan yang diharapkan tercapai. Semangat, kejujuran, belas kasih, dan cinta merupakan contoh instrumental values. Sedangkan terminal values adalah pernyataan-pernyataan tujuan atau cita-cita yang ingin dicapai sepanjang hidup, seperti nilai-nilai kebijaksanaan, keselamatan, kemakmuran dan sebagainya. Selain itu, ada juga nilai-nilai personal yang bersifat tangible dan intagible.

Nilai-nilai tangible adalah sesuatu yang dapat dilihat, dirasakan atau dipegang, termasuk jenis mobil yang dikendarai, level pendapatan yang anda ingin dimiliki, ukuran rumah yang ingin ditempati. Nilai-nilai tangible terdiri dari barang-barang material yang ingin dimiliki. Sedangkan nilai-nilai intagible meliputi kebebasan, independensi, kebahagiaan, pertemanan, dan cita. Nilai-nilai intangible dapat didefenisikan secara berbeda oleh setiap orang. Nilai-nilai intagible terdiri dari gagasan yang ingin dicapai dan dikejar. 
Ada beberapa langkah strategis yang mendukung kemajuan untuk mencapai sebuah cita-cita. Pertama, visualize outcome. Bayangkan seolah-olah cita-cita telah tercapai. Kedua, fokus pada proses berusaha, bukan pada hasil. Yang seharusnya dilakukan dengan prinsip terbaik, harus diusahakan. Ketiga, mengembangkan dukungan jaringan. Tentukan sumber daya yang akan menjadi kebutuhan untuk mencapai cita-cita. Dukungan dan komitmen dari individu-individu akan menjadi esensial untuk menjamin kesuksesan.

Keempat, fokus pada satu tujuan atau cita-cita. Terlalu banyak cita-cita akan hanya menguras pikiran dan mengurangi potensi terbaik untuk mencapai cita-cita tersebut. Kelima, manusiawi jika membuat kesalahan saat mencoba untuk mencapai tujuan. Memaafkan diri sendiri dan kembali ke rencana semula. Jika tidak bergerak, tujuan tidak akan tercapai.

Keenam, jujur pada diri sendiri. Evaluasi secara objektif bagaimana sebaiknya cita-cita dan tujuan-tujuan itu terselesaikan. Satu-satunya cara yang dapat ditingkatkan adalah memahami kesalahan yang telah dilakukan dan fokus bagaiman hal itu dapat diubah.

Ketujuh, hargai setiap keberhasilan kecil. Sekali tahapan tujuan atau tonggak tercapai, berilah penghargaan terhadap pencapaian itu. Merayakan setiap pencapaian akan mempertahan omptimisme. Dan percaya bahwa kemampuan untuk mencapai tujuan selanjutnya dimiliki.

Kedelapan, jangan kehilangan gambaran besar mengenai tujuan yang ingin dicapai. Setiap pencapaian-pencapaian kecil harus selalu dikembalikan pada tujuan besar anda. Dengan cara ini komitmen untuk mencapai cita-cita selalu diperkuat kembali. Dan kesembilan adalah merevisi proses. Goal setting tidak pernah selesai dalam satu proses, melainkan sebuah proses yang terus berlangsung. Dengan merevisi proses ini, sumber daya untuk mengatasi hambatan dan tantangan yang dihadapi terus dievaluasi.

Dari deskripsi di atas sekurang-kurangnya goal setting melibatkan 4 unit tindakan, yakni: 1) aktor yang merencanakan sebuah goal, 2) aktor mendesain sebuah kerangka kerja untuk mencapai goal (goal setting), 3) goal yang ingin dicapai oleh seorang aktor, dan 4) nilai-nilai yang mendeterminasi seorang aktor untuk untuk menentukan tujuan atau cita-cita yang ingin dicapai dan cara mencapai cita-cita tersebut. Untuk lebih jelasnya, penjelasan di atas dapat diringkas melalui kerangka berikut.

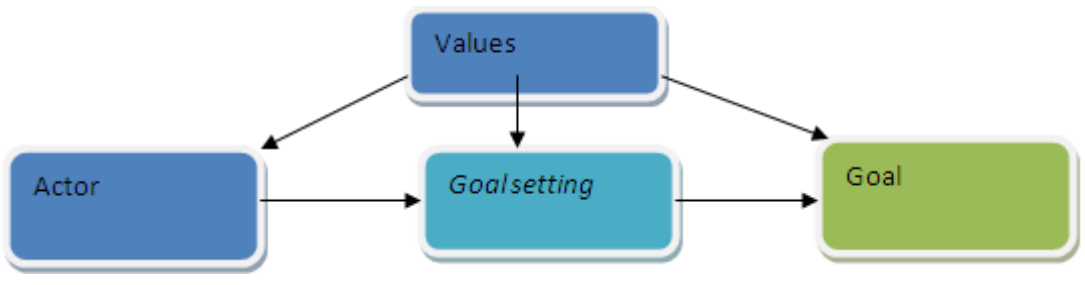

Gambar 1 Alur Goal Setting

Nilai-nilai merupakan faktor determinan bagi seorang aktor baik dalam goal setting yang dirancangnya maupun dalam cita-cita yang ditetapkan untuk dicapai. Berdasarkan kerangka tersebut, maka goal setting dan goal yang dirancang dan ditetapkan oleh seorang aktor, secara teoretis dan paradigmatis, bersifat struktural dan fungsional. Baik rancangan, kerangka kerja maupun tujuan atau cita-cita yang ingin dicapai oleh seorang aktor selalu, baik langsung maupun tidak langsung, mecerminkan nilai-nilai yang sedang hidup dalam suatu komunitas. Dalam konteks ini, goal setting dan goal yang dirancang dan ditetapkan oleh seorang aktor secara teoretis dan paradigmatis merupakan suatu bentuk tindakan sosial. 


\section{Tindakan Sosial}

Menurut Parson (dalam Turner, 1998), sebuah tindakan sosial selalu melibatkan beberapa unit tindakan. Unit-unit tindakan itu terdiri dari: 1) Aktor; seorang aktor adalah subjek individual. 2) Aktor memiliki goal setting. 3) Aktor memiliki berbagai macam alat untuk mencapai goal-nya. 4) Aktor dikonfrotasikan dengan berbagai macam kondisi situasional seperti faktor lingkungan, biologis, dan faktor lain-lain. Faktor-faktor situasional ini turut memengaruhi penentuan goal dan alat-alat yang digunakan untuk mencapai goal. 5) Aktor diatur oleh nilai-nilai, norma-norma, dan berbagai gagasan. Nilai-nilai, norma-norma, dan berbagai gagasan tersebut sangat memengaruhi penentuan goal dan alat yang dipilih untuk mencapai goal. Dan, 6) tindakan yang melibatkan pembuatan keputusan subjektif tentang alat untuk mencapai goal. Semua ini ditentukan oleh gagasan-gagasan dan kondisi-kondisi situasional. Untuk memperjelas konsepsi Parson mengenai tindakan sosial yang dilakukan oleh seorang aktor, lihat gambar berikut.

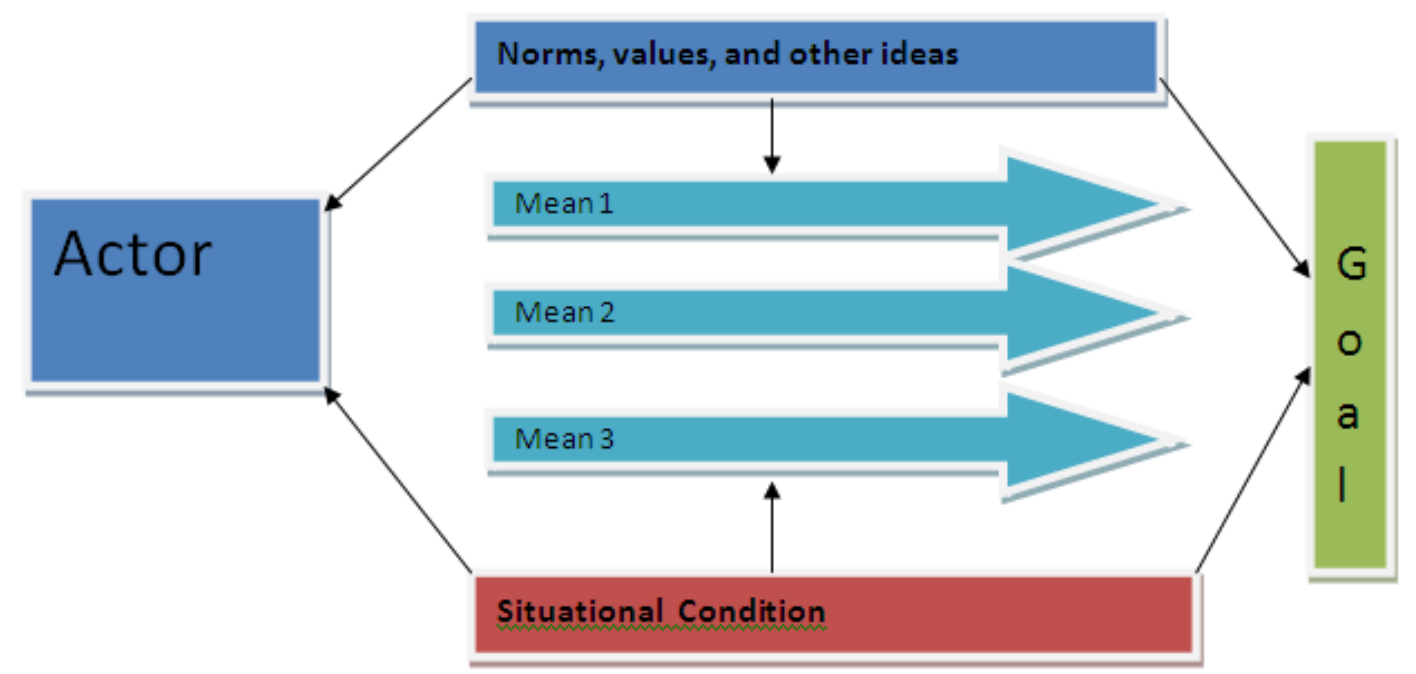

Gambar 2 Konsepsi Parson tentang Tindak Sosial

(Sumber: Turner, 1998: 30)

Dari penjelasan di atas nampak jelas bahwa, Parson melihat goal yang dilakukan oleh seorang aktor dideterminasi oleh dua faktor penting, yakni kebudayaan (sistem nilai, norma, dan berbagai pandangan yang hidup dalam sebuah organisasi) dan kondisi-kondisi yang bersifat situasional. Berdasarkan penjelasan dan skema konseptual yang dikemukakan Parson di atas, maka tujuan yang hendak dicapai oleh seorang actor individu selalu ditempatkan dalam kerangka budaya dan kondisi yang bersifat situasional. Demikian pula instrumen atau alat atau strategi yang digunakan oleh seorang aktor untuk mencapai tujuannya juga dibatasi oleh dua faktor tersebut. Seorang aktor akan memilih sebuah instrumen yang paling efektif untuk mencapai tujuan-tujuannya. Meskipun demikian, instrumen yang digunakan untuk mencapai tujuan selalu diadaptasikan dengan kedua faktor determinan tersebut.

Dalam menetapkan tujuan tindakan dan alat yang akan digunakan untuk mencapai tujuan itu, seorang aktor diorientasikan oleh dua aspek mendasar, yakni aspek motivasional dan nilai. Menurut Parson aspek motivasional terdiri dari tiga komponen, yakni: kognitif yaitu kebutuhan untuk informasi; katetik yaitu kebutuhan untuk dukungan emosional; dan evaluatif merupakan kebutuhan assessment. 
Seperti aspek motivasional, aspek nilai juga terdiri dari tiga komponen, yakni: kognitif yaitu kebutuhan untuk evaluasi dengan standar-standar yang obyektif; apresiatif yaitu evaluasi dengan standar-standar estetik; dan moral yaitu evaluasi dengan menggunakan standar-standar mengenai yang benar dan yang salah.

Berdasarkan dua aspek yang mendorong seorang aktor dalam menetapkan tujuan dan memilih alat yang digunakan untuk mencapai tujuan tersebut, Parson mengemukakan bahwa ada tiga tipe tindakan yang biasa dilakukan oleh seorang actor. Ketiga tipe tindakan tersebut adalah tindakan instrumental, ekspresif, dan moral. Tindakan instrumental diorientasikan untuk merealisasikan tujuantujuan yang eksplisit secara efisien. Sedangkan tindakan ekspresif merupakan tindakan yang diarahkan untuk kepuasan-kepuasan emosional. Dan tindakan moral dikonsentrasikan untuk merealisasikan standar-standar tentang kebenaran dan kesalahan. Jenis tindakan yang akan dipilih oleh seorang aktor individual, menurut Parson, sangat tergantung pada aspek orientasi yang lebih kuat: motivasional atau nilai. Sebagai contoh, jika motif kognitif lebih kuat dan nilai kognitif lebih lemah dari motif kognitif, tindakan aktor individu tersebut dapat dikategorikan sebagai tindakan instrumental. Demikian juga sebaliknya, jika suatu tindakan diorientasikan oleh nilai moral, jenis tindakan tersebut bersifat moral. Demikian seterusnya.

Berdasarkan penjelasan Parson tersebut, maka aktor yang menetapkan tujuan hidupnya dan strategi yang digunakannya untuk mencapai tujuan tersebut bukan merupakan seorang individu yang bebas. Sebab, tujuan dan sarana-sarana yang ia tetapkan dan pilih untuk mencapai tujuannya itu mecerminkan pandangan-pandangan, nilai-nilai, dan norma-norma yang yang hidup dalam masyarakat. Di samping itu juga dideterminasi oleh faktor-faktor yang bersifat kondisional.

Menurut Parson, seorang aktor individu akan selalu bertindak dengan cara demikian. Dan oleh karena itu, hampir-hampir tidak ada kemungkinan seorang individu bertindak lain di luar pandanganpandangan, nilai-nilai, dan norma-norma yang hidup dalam masyarakat. Konstruksi Parson mengenai tindakan sosial manusia yang dideterminasi oleh faktor budaya dan kondisi-kondisi yang bersifat situasional sebetulnya berakar pada fungsionalisme yang telah dikembangkan oleh E. Durkheim sebelumnya. Menurut Durkheim, tindakan setiap orang selalu dideterminasi oleh fakta sosial tertentu.

Fakta sosial menurut Durkheim memiliki kekuatan yang menyuruh dan memaksa individu, terlepas dari apakah individu itu mau atau tidak. Bahkan kata Durkheim, sekalipun individu itu merasa tidak terpaksa melakukan sesuatu atau melakukan sesuatu berdasarkan kemauannya sendiri, sifat intrinsik dari fakta sosial itu yang bersifat memaksa tetap menjadi jelas: karena saya tidak dapat berbuat sesuatu yang lain kecuali harus sesuai dengan kebiasaan-kebiasaan yang telah diwariskan sejak sebelum saya lahir. Ketika saya lahir kebiasaan-kebiasaan itu telah ada, saya yang mempelajarinya melalui proses sosialisasi.

Melalui proses sosialisasi inilah cara saya merasa, berpikir, dan bertindak lebih mencerminkan fakta-fakta yang bersifat objektif dan eksternal. Kalau setiap orang dibesarkan dengan cara sosialisasi yang sama, besar kemungkinan setiap orang yang dibesarkan dengan cara sosialisasi yang sama akan berpikir, bertindak, dan berperasaan dengan cara yang sama pula. Ini artinya, bahwa sosialisasi membentuk apa yang disebut oleh Durkheim sebagai kesadaran kelompok (collective consciousness). Kesadaran kelompok mencerminkan suara hati kolektif (collective conscience). Ini berarti bahwa cara saya berpikir, bertindak dan berperasaan bukan merupakan gejala yang bersifat biologis ataupun psikologis, melainkan sebuah gejala yang dapat diamati dalam masyarakat itu sendiri. Selain menunjukan sifat-sifatnya yang objektif, eksternal, dan koersif, fakta sosial itu juga memiliki sifat kolektif. Gejala kolektif ini merupakan suatu gejala yang sungguh berisifat umum. Gejala ini bersifat umum, menurut Durkhiem, semata-mata karena sifatnya yang kolektif, dan bukan sebaliknya.

Berdasarkan uraian singkat di atas maka, secara tegas Durkheim merumuskan bahwa suatu fakta sosial ditandai oleh kekuatan pemaksaan yang bersifat eksternal yang diterapkan atau yang 
sanggup diterapkan pada individu-individu. Adanya kekuatan pemaksaan tersebut ditandai oleh adanya sanksi-sanksi tertentu. Sifat-sifat atau karakteristik dari fakta sosial seperti yang dijelaskan sebelumnya dapat diamati dalam gejala-gejala seperti hukum, moral, kepercayaan-kepercayaan, norma-norma, adat istiadat. Gejala-gejala sosial ini ada yang dibakukan dalam rumusan-rumusan dan ada juga yang hanya diteruskan melalui kebiasaan-kebiasaan oral.

Namun meskipun berakar dari Durkheim, pemikiran Parson lebih menempatkan seorang aktor individu yang lebih dinamis bila dibandingkan dengan Durkheim. Bagi Durkheim, aktor individu benar-benar tidak berdaya terhadap fakta sosial di tempat ia hidup. Berbeda dengan Durkheim, Parson masih percaya bahwa dalam memilih alat-alat dan bahkan ketika menetapkan sebuah tujuan, seorang aktor masih dapat memilih salah satu goal dan instrument yang paling efektif dan efisien. Melalui penjelasannya ini, Parson ingin menjelaskan aspek rasionalitas dari sebuah tujuan (goal) dan cara (means) yang digunakan untuk mencapai tujuan, meskipun aspek rasionalitas tidak bersifat total seperti yang diasumsikan oleh Max Weber, Jean-Jacques Rosseau, dan William Isaac Thomas.

Menurut Weber (Wallace dan Wolf, 2006: 200), setiap individu memiliki interpretasi terhadap suatu situasi dan individu yang sama memiliki makna subjektif terhadap suatu peristiwa. Dalam kaitan dengan ini, Weber, seperti diulas oleh Perdue (1986: 177), mengemukakan bahwa suatu tindakan sosial selalu terjadi pada dua kondisi yang saling berhubungan satu dengan lain. Pertama, orang memiliki makna subjektif yang berasal dari gagasan-gagasan yang sebelumnya nampak dalam dunia pengalaman mereka. Kedua, sebuah tindakan memiliki makna sosial bila aktor mempertimbangkan perilaku dari orang lain yang ditentukan oleh harapan-harapan mereka. Dengan kata lain, demikian komentar Perdue, pemikiran (thought), kognisi, dan orientasi kepada yang lain merupakan sesuatu yang krusial untuk membentuk perilaku sosial. Lebih tegas dari Weber, JeanJacques Rosseau (Perdue, 1986: 157) mengemukakan bahwa "man was born free, and he is everywhere in chains". Peran individu yang aktif dalam hubungan sosial dapat kita temukan juga dalam pandangan William Isaac Thomas (Wallace dan Wolf, 2006: 202). Thomas terkenal dengan konsepnya mengenai "definition of the situation". Menurutnya, individu memiliki kekuasaan untuk mengabaikan suatu stimulus yang mereka terima pada saat sebelumnya. Definisi terhadap situasi memiliki konsekuensi behavioral yang penting. Bila seseorang mendefinisikan sesuatu itu riil, maka sesuatu itu riil dalam konsekuensinya. Oleh karena itu, Thomas menegaskan bahwa kita tidak pernah memahami aktivitas manusia, kecuali kita berusaha memahami makna subjektif dan definisi situasi seorang aktor.

\section{Values of Binus dan Pembelajaran Character sebagai Goal Setting}

Salah satu perhatian penting Binus bagi setiap lulusannya adalah memiliki karakter binusian. Karakter binusian itu adalah nilai-nilai yang diyakini Binus menjadi unsur inti yang menggerakkan para binusian untuk menjadi. Nilai-nilai itu meliputi: Trust In God, Tenacious Focus, Freedom to Innovate, Farsighted, Embrace Diversity. Nilai-nilai ini dapat saja dianggap sebagai kekuatan evolutif yang menggerakkan para binusian menuju tujuan mareka.

Meskipun tidak ada penjelasan resmi mengenai dasar filosofis dari masing-masing nilai ini, berdasarkan kerangka berpikir seperti yang telah dideskripsikan, diasumsikan bahwa nilai-nilai tersebut merupakan habitus yang direproduksi dan rekonstruksi kembali dari nilai-nilai, pandangan hidup, dan kepercayaan para pendiri tentang bagaimana para binusian harus menjadi pada masa depan.

Berdasarkan asumsi itu, maka para binusian harus memiliki nilai-nilai spiritualitas. Nilai-nilai ini harus tercermin dalam tujuan atau cita-cita hidup mereka, dan cara yang mereka gunakan untuk mencapai cita-cita itu pun harus mencerminkan nilai-nilai spiritualitas tersebut. Nilai-nilai spiritualitas dapat mencakup 'kesadaran untuk peduli, berpartisipasi dalam perdamaian, setia pada kebenaran, krits, tanggung jawab, toleransi, kerja sama' (lihat modul CB: Spiritual Development). 
Selain itu, para binusian harus ulet (tenacious focus). Keuletan pada prinsipnya merupakan salah satu keutamaan moral. Tentang kutamaan keuletan ini, Bertens (2006: 79) menulis:

\begin{abstract}
"Pebisnis harus bertahan dalam banyak situasi yang sulit. Ia harus sanggup mengadakan negosiasi yang terkadang seru tentang proyek atau transaksi yang bernilai besar. Ia juga harus berani mengambil risiko kecil maupun besar... ia tidak akan patah semangat di tengah kekecewaan dan kesulitan dan kesulitan... keuletan dalam bisnis itu cukup dekat dengan keutamaan lebih umum yang disebut keutamaan moral.”
\end{abstract}

Setiap binusian harus ulet dalam menghadapi setiap tantangan. Dasar dari setiap keuletan tentu saja lahir dari kesadaran tentang potensi diri setiap para binusian. Untuk itu, refleksi potensi diri menjadi sangat penting, dan terus belajar untuk mengaktualisasikan potensi harus menjadi karakter para binusian (lihat CB: Self Development).

Di samping keutamaan keuletan, para binusian harus menghayati nilai kebebasan untuk berinovasi. Kebebasan secara filosofis selalu mengandaikan adanya penghormatan terhadap harkat dan martabat manusia. Oleh karena itu, nilai-nilai kebebasan selalu disertai dengan prinsip-prinsip keadilan. Dan secara klasik keadilan selalu didefinisikan sebagai: memberikan kepada setiap orang yang menjadi haknya (Bertens, 2006: 87). Dalam konteks ini, maka kebebasan untuk berinovasi (freedom to innovate) memuat dengan sendirinya nilai-nilai etis. Bila nilai ini dianalisis lebih jauh, inovasi yang diharapkan lahir dari para binusian mendorong bertumbuhnya nilai-nilai inklusivitas dalam masyarakat. Artinya, inovasi itu tidak memperbesar kesenjangan antara yang lemah dengan yang kuat. Inovasi itu menumbuhkan dan memungkinkan partisipasi semua orang dalam memajukan kehidupan, baik sebagai pribadi maupun sebagai anggota masyarakat (lihat CB: Professional Development).

Binus menyadari bahwa para binusian tidak akan pernah berada dalam kelompok masyarakat yang homogen. Masyarakat sekarang ini hidup dalam keterbukaan, baik karena kemajuan teknologi, transportasi maupun teknologi informasi. Kemajuan-kemajuan teknologi ini telah memungkinkan mobilitas masyarakat dari satu tempat ke tempat lain menjadi sangat fleksibel. Teknologi informasi telah menghadirkan kemudahan berbagai informasi dapat diakses dengan lebih cepat. Dalam kondisi seperti ini para binusian akan berada dan bekerja dengan berbagai macam orang dengan latar belakang yang beragam, baik dari segi agama, ideologi, ras, kebudayaan maupun kelas sosial. Ini berarti para binusian harus memiliki nilai-nilai yang sanggup menghargai perbedaan (embrace diversity).

Namun untuk dapat menghargai perbedaan tersebut, para binusian harus memiliki kemampuan komunikasi, kepemimpinan, negosiasi, persuasi, memahami nilai-nilai dan norma-norma yang berlaku dalam suatu kelompok masyarakat baik di lingkungan kerja maupun masyarakat secara keseluruhan. Keterampilan interpersonal seperti ini dibangun di atas dasar hubungan yang etis dengan orang lain. Orang lain dalam hal ini bukan semata-mata orang lain yang berbeda dengan saya. Orang lain adalah sesama manusia juga. Karena orang lain itu adalah sesama manusia, maka berlakulah prinsip moral "Golden Ways" yakni perlakukan orang lain seperti anda mengharapkan orang memperlakukan anda. Praktik-praktik komunikasi, kerja sama, negosiasi, persuasi, dan kepemimpinan, dilakukan dengan semangat moral ini (CB: Interpersonal Development).

Secara teoretis, penjelasan-penjelasan di atas dapat diringkas dalam bagan berikut ini. 


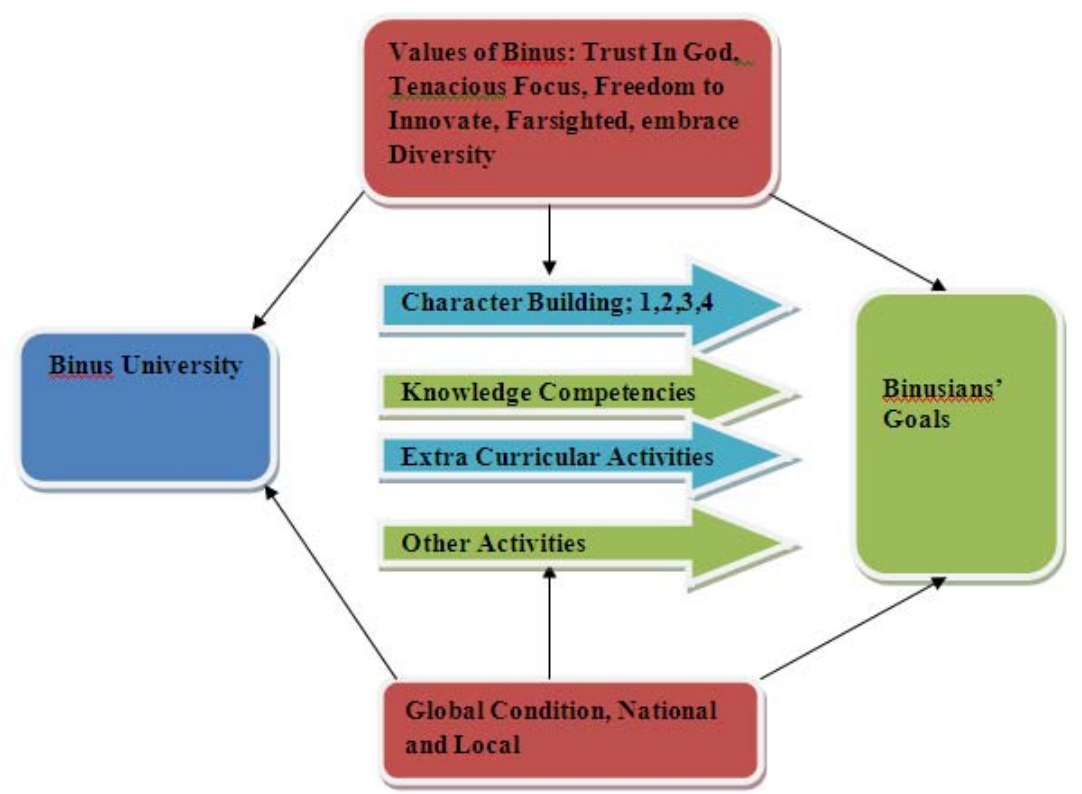

Gambar 3 Bagan Values Of Binus dan Pembelajaran Character di Binus

\section{Implikasi Teoretik}

Berdasarkan deskripsi di atas, maka implikasi teoretik untuk pembelajaran character building tidak saja memuat tuntutan-tuntutan yang bersifat kondisional yang cenderung pragmatis, yakni untuk memenuhi permintaan pasar tenaga kerja, yang cenderung fleksibel, berubah dengan standar-standar yang beragam.

Pendidikan Character Building di Binus University lebih dari melatih para binusian untuk memiliki soft skill. Para binusian tidak hanya memiliki kemampuan komunikasi, kerja sama, manajemen diri, inisiatif dan semangat kewirausahaan, tetapi juga memiliki kemampuan untuk memecahkan masalah dan pembuatan keputusan etis dan kempuan berorganisasi. Lebih dari kemampuan dalam bidang soft skill, para binusian memiliki karakter yang memuat nilai-nilai Binus itu sendiri. Nilai-nilai Binus harus menjadi api yang menggerakkan yang nampak dalam soft skill dan hard skill mereka.

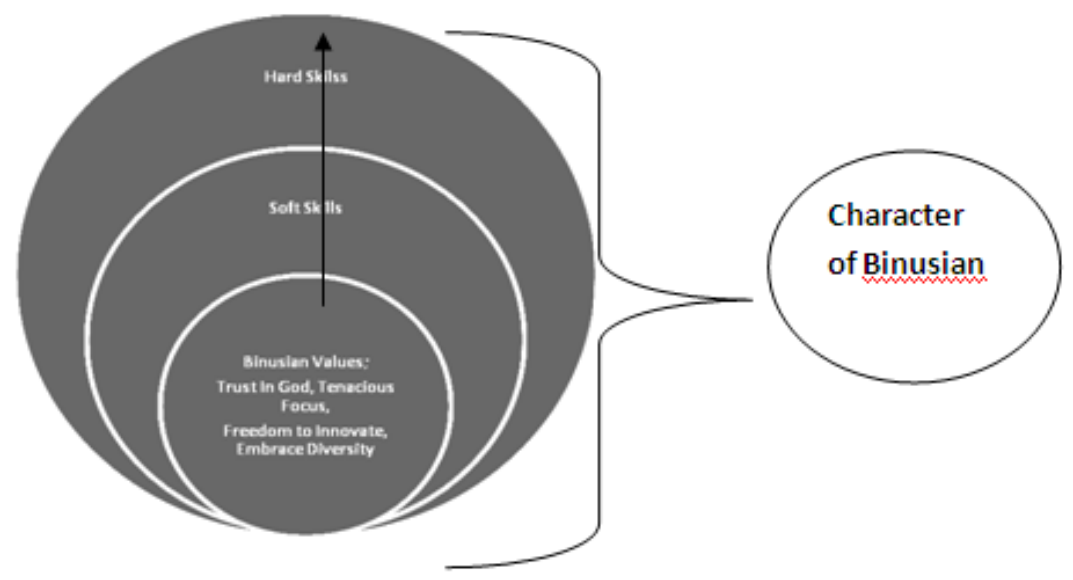

Gambar 4 Karakter Binusian 
Berdasarkan deskripsi tersebut, binusian sebetulnya memuat tiga aspek mendasar dalam kepibadiaannya. Ketiga aspek tersebut adalah binusian values, soft skill, dan hard skill. Ketiga aspek ini merupakan satu kesatuan yang membentuk kepribadian binusian. Kepribadian binusian yang dikonstruksi oleh ketiga aspek ini menjadi faktor pembeda antara para binusian dan yang bukan binusian. Nilai-nilai dasar binusian akan nampak dalam soft skill yang ditampilkannya dan hard skill yang dimilikinya dalam memuat nilai-nilai binusian.

Berdasarkan penjelasan di atas, maka kompetensi para binusian dalam menghadapi tantangan global tidak semata-mata terletak pada soft skill dan hard skill yang mereka miliki. Kompetensi para binusian juga sangat tergantung pada sejauh para binusian dapat mengiternalisasi nilai-nilai binusian ke struktur kepribadian mereka.

Jika nilai-nilai binusian terinternalisasi dalam struktur kepribadian binusian, baik cara pandang maupun cara hidup para binusian harus mencerminkan nilai-nilai tersebut. Mekanisme sosialisasi melalui konstruksi kurikulum, implemetasinya dalam proses pembelajaran, dan konten setiap materi, terutama materi Character Building harus memuat nilai-nilai itu.

\section{SIMPULAN}

Pembelajaran Character Building pada Binus University merupakan salah satu instrumen yang digunakan untuk mensosialisasikan nilai-nilai Binus. Oleh karena itu, pembelajaran Character Building tidak semata-mata ditujukan untuk melatih para mahasiswa untuk memiliki soft skill, namun sebuah keterampilan yang sangat dibutuhkan oleh masyarakat pada umumnya dan masyarakat kerja serta bisnis pada khususnya. Pembelajaran Character Building pada Binus University terutama menanamkan nilai-nilai Binus dalam diri para mahasiswa. Nilai-nilai ini dapat dianggap sebagai cultural capital, yang tidak hanya membedakan para binusian dari yang bukan binusian di tengah masyarakat, baik masyarakat politik, sosial, maupun ekonomi, tetapi juga capital yang memiliki nilai lebih di tengah berbagai tawaran nilai hidup dalam masyarakat global dewasa ini. Diharapkan dengan menghayati nilai-nilai tersebut aktualisasi potensi para binusian dapat menjadi sumber inspirasi bagi masyarakat, tempat mereka berada.

\section{DAFTAR PUSTAKA}

Bertens, K. (2006). Pengantar Etika Bisnis. Yogyakarta: Kanisius.

Janasz, S. C. De, et. al., (2006). Interpersonal Skill in Organizations. New York: McGraw Hill.

Ritzer, G., \& Goodman, D. J. (2004). Sociological Theory. New York: McGraw-Hill.

Turner, J. H. (1998). The Structure of Sociological Theory. New York: Wadsworth.

Wallace, R. A., \& Wolf, A. (2005). Contemporary Sociological Theory, Expanding The Classical Tradition. New Jersey: Pearson Prentice Hall. 